\title{
Conservation system improves soil microbial quality and increases soybean yield in the Northeastern Cerrado
}

\author{
Maria de Fátima Marques Pires ${ }^{1}$ (D), João Carlos Medeiros² (D), Henrique Antunes de Souza3 (iD,

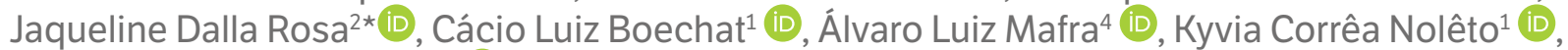 \\ Angélica Gomes da Rocha ${ }^{1}$ (D) \\ 1. Universidade Federal do Piauí - Campus Professora Cinobelina Elvas - Bom Jesus (PI), Brazil. \\ 2. Universidade Federal do Sul da Bahia - Centro de Formação em Ciências Agroflorestais - Itabuna (BA), Brazil. \\ 3. Empresa Brasileira de Pesquisa Agropecuária - Embrapa Meio-Norte - Teresina (PI), Brazil. \\ 4. Universidade do Estado de Santa Catarina - Centro de Ciências Agroveterinárias - Lages (SC), Brazil.
}

\begin{abstract}
The conservation tillage systems is based on the surface protection by crop residue and reduced soil disturbance. These two principles can favor the soil quality and promote sustainable agricultural systems. The study was developed with the objective of measure soil microbial biomass, soil basal respiration, enzymatic activity and soybean yield in conservation systems cultivated with cover crops species in the Northeastern Cerrado. The experiment was carried out in 2016/2017 and 2017/2018 cropping seasons, performed in a randomized blocks design. The treatments were soil tillage systems allocated in the main plots: no-tillage (NT) and minimum tillage (MT) and the cover crops were allocated in the subplots: Pennisetum glaucum (millet), Urochloa ruziziensis (brachiaria), Crotalaria spectabilis (C. spectabilis), Crotalaria ochroleuca (C. ochroleuca), Pennisetum glaucum + Crotalaria spectabilis (millet + C. spectabilis) and spontaneous plants with three replicates. The evaluated variables were dry mass (DM) production and nutrient accumulation in cover crops; soil biological properties, namely microbial biomass carbon and nitrogen (MBC and MBN, respectively), respiration, metabolic quotient $\left(\mathrm{qCO}_{2}\right)$, dehydrogenase enzymatic activity $(\mathrm{DH})$, fluorescein diacetate (FDA); and soybean yield. The higher production of dry mass and nutrient cycling occurs with the intercropping millet $+C$. spectabilis and single millet. The highest soybean yield occurs in succession to $C$. ochroleuca and intercropping of the millet $+C$. spectabilis. Cover crops in conservation systems improve soil microbial quality and increase soybean yield.
\end{abstract}

Key words: Glycine max L., soil quality, no-tillage, nutrient cycling, microbial biomass.
Received:

Mar. 20, 2020

Accepted:

Jul. 21, 2020

Section Editor:

Osvaldo Guedes Filho

${ }^{*}$ Corresponding author: jaqueline.rosa@ufsb.edu.br

\section{INTRODUCTION}

The agricultural expansion in the Northeastern Cerrado is a result of good soil management practices, especially lime application, improved fertility through mineral fertilization and proper phytosanitary management, which make this region, partly situated in MATOPIBA, one of the last Brazil's agricultural borders (Almeida et al. 2018). Soybean (Glycine max L. Merrill), which presents good adaptation and high yield, is the crop with the largest planted area in the Northeastern Cerrado. Due to the good profitability of soybean, the cultivation system is little diversified, resulting in large monoculture areas. In this production system, cover crops are rarely included, resulting in low production of crop residues and insufficient soil cover throughout the year (Merten et al. 2015).

Low soil cover may make no-tillage system unfeasible and low residue production compromises soil organic carbon stocks, nutrient cycling, microbiological activity and, consequently, soil quality (Pacheco et al. 2017; Derpsch et al. 2014). 
Thus, one of the current challenges for agriculture in the Northeastern Cerrado is to develop management practices that improve soil quality in order to ensure its sustainability. This can be achieved by using the conservation systems (used as synonym of conservation agriculture) with crop rotation plans, including cover crops to increase residue production and soil protection (Osterholz et al. 2020).

The main characteristics of cover crops to their selection and use are soil and climate adaptation that are necessary to ensure sufficient mass production and proper nutrient cycling. Characteristics such as lignin content, rooting growth and ability to establish symbiosis with nitrogen fixing bacteria and their capacity to improve physical, chemical and microbiological soil properties should also be considered (Adler et al. 2020; Amorim et al. 2020; Sousa et al. 2019).

Cover crop residues can improve water availability and thermal conditions, which favors growth and microbial activity and may increase soil carbon and nitrogen stocks (De Vincentis et al. 2020). Soil microbiota plays a fundamental role in organic matter decomposition and nutrient cycling, since the mineralization of crop residues depends on the presence and activity of these organisms (Castellano-Hinojosa and Strauss 2020; Mbuthia et al. 2015). In addition, biomass and soil microbial activity are important indicators of soil quality (Balota et al. 2014). Thus, by using cover crops it is possible to improve soil microbial properties and increase crop yields over the years (Amorim et al. 2020; Chamberlain et al. 2020). Long-term no-tillage and use of cover crops can improve structure, activity and conditions of the microbial community, with better $\mathrm{C}, \mathrm{N}$ and $\mathrm{P}$ cycling that may increase crop yields compared to conventional soil plowing (Mbuthia et al. 2015). However, studies that relate conservation systems, cover crops, soil microbial and enzymatic activity and their effect on agricultural crop yields are still needed in the Northeastern Cerrado region.

The hypothesis tested in this study was that the use of cover crops in a no-tillage system improves soil quality and microbial activity, making it more efficient in nutrient cycling and, consequently, boosting soybean yield. The experiment was developed with the objective of measure soil microbial biomass, soil basal respiration, enzymatic activity and soybean yield in conservation systems cultivated with cover crops species in the Northeastern Cerrado.

\section{MATERIAL AND METHODS}

\section{Experiment location}

The experiment was carried out in the municipality of Bom Jesus, in Serra do Quilombo (Vô Desidério farm), with geographic coordinates of $09^{\circ} 16^{\prime} 20^{\prime \prime} \mathrm{S}$ and $44^{\circ} 56^{\prime} 56^{\prime \prime} \mathrm{W}$. The average altitude of the experimental area is $610 \mathrm{~m}$ and the mean slope is $0.2 \%$. The climate of the region is characterized as tropical with dry winter (Aw according to Köppen's classification), with an average annual temperature of $26.6^{\circ} \mathrm{C}$ and an average rainfall of $1,100 \mathrm{~mm} \cdot$ year $^{-1}$. There are two well-defined seasons in the year: a rainy season from November to April and a dry season from May to October, without rainfall (Andrade Junior et al. 2004). Data of air temperature and rainfall in the experimental area during soybean cropping season are described in Fig. 1.

The soil is a typical oxisol (Soil Survey Staff 2014) with $220 \mathrm{~g} \cdot \mathrm{kg}^{-1}$ clay. Prior to the installation of the experiment, soil samples were collected in the $0-0.2 \mathrm{~m}$ and $0.2-0.4 \mathrm{~m}$ layers for soil chemical and particle size characterization (Table 1).

The experimental area has been cultivated in a no-tillage system for 11 years, using millet as an interseasonal cover crop. Soybean crops have been in the area for 18 years, and only in the 2013, cropping season there was intercropping corn + brachiaria.

\section{Experimental design}

The experiment was carried out in a randomized block design, in split-plot arrangement, using soil tillage in the main plot and cover crops in subplots, with three replicates. Conservation systems consisted of no-tillage (NT) and minimum tillage (MT) performed with a disking at a depth of $0.3 \mathrm{~m}$, preceding the sowing of cover crops. The cover crops used were selected based on previous studies already made in the region (Sousa et al. 2019; Pacheco et al. 2017). 


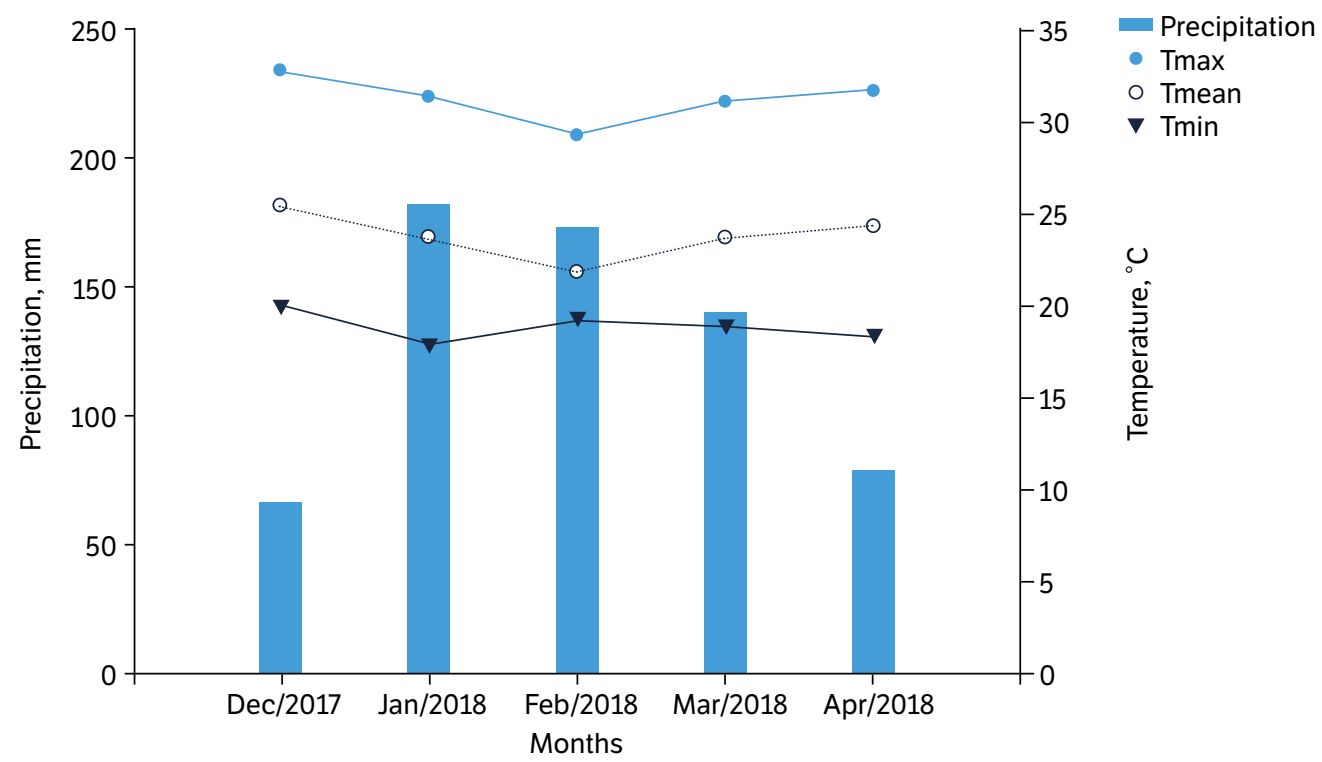

Figure 1. Precipitation and air temperature (maximum, mean and minimum), in the 2017/2018 growing season, when the experiment was carried out at Vô Desidério Farm, Bom Jesus, PI.

Table 1. Soil chemical properties and particle size distribution before the implementation of the experiment.

\begin{tabular}{|c|c|c|c|c|c|c|c|c|}
\hline Depth & $\mathrm{pH}$ & BS & $\mathrm{H}+\mathrm{Al}$ & Al & $\mathrm{Ca}$ & $\mathrm{Mg}$ & SB & CEC \\
\hline m & $\left(\mathrm{H}_{2} \mathrm{O}\right)$ & $\%$ & \multicolumn{6}{|c|}{$\mathrm{cmol}_{\mathrm{c}} \cdot \mathrm{dm}^{-3}$} \\
\hline $0-0.2$ & 5.5 & 36 & 5.7 & 0.1 & 2 & 0.8 & 3.2 & 9.0 \\
\hline $0.2-0.4$ & 5.2 & 29 & 4.2 & 0.2 & 1 & 0.3 & 1.7 & 5.8 \\
\hline Depth & $\mathbf{P}$ & $\mathbf{K}$ & $\mathrm{S}-\mathrm{SO}_{4}{ }^{2-}$ & AS & OM & Clay & Silt & Sand \\
\hline $\mathrm{m}$ & & $\mathrm{mg} \cdot \mathrm{dm}^{-3}$ & & $\%$ & \multicolumn{4}{|c|}{$\mathbf{g} \cdot \mathbf{k g}^{-1}$} \\
\hline $0-0.2$ & 56.5 & 177.7 & 16.5 & 3 & 20 & 223 & 5 & 772 \\
\hline $0.2-0.4$ & 19.4 & 122.5 & 17.1 & 10 & 12 & 234 & 20 & 746 \\
\hline
\end{tabular}

Al: aluminum; BS: base saturation; Ca: calcium; CEC: cation exchange capacity; H+AL: potential acidity; K: potassium; AS: aluminum saturation; Mg: magnesium; OM: Organic matter. P: phosphorus; SB: sum of bases; $\mathrm{S}_{-} \mathrm{SO}_{4}^{2 *}$ : sulfur in the form of sulfate.

The cover crops were Pennisetum glaucum (millet), Urochloa ruziziensis (brachiaria), Crotalaria spectabilis (C. spectabilis), Crotalaria ochroleuca (C. ochroleuca), intercropping of Pennisetum glaucum + Crotalaria spectabilis (millet + C. spectabilis) and spontaneous plants, with predominance of the following species: Alternanther atenella L., Eleusine indica L., Cenchrus echinatus L. and Sida glaziovii L.

The area corresponding to each experimental block had $30 \times 13 \mathrm{~m}$ and each plot $5 \times 6.5 \mathrm{~m}$. The cover crops were sown in both systems in mid-December 2016, manually and by broadcasting.

The quantities of seeds used were: millet: $30 \mathrm{~kg} \cdot \mathrm{ha}^{-1}$, brachiaria: $25 \mathrm{~kg} \cdot \mathrm{ha}^{-1}$; C. ochroleuca: $10 \mathrm{~kg} \cdot \mathrm{ha}{ }^{-1}$; C. spectabilis: $20 \mathrm{~kg} \cdot \mathrm{ha}^{-1}$. Intercropping: $10 \mathrm{~kg} \cdot \mathrm{ha}^{-1}$ of millet $+15 \mathrm{~kg} \cdot \mathrm{ha}^{-1}$ of C. spectabilis. The plants were sown and incorporated with a light harrowing at a depth of 3 to $5 \mathrm{~cm}$. Fertilization was not used to grow cover crops. A reseeding was required in midJanuary 2017 due to germination failures.

\section{Dry mass and nutritional analysis of cover crops}

The evaluation of dry mass (DM) production of cover crops was performed at 105 days after the beginning of germination in March 2017. A $0.25 \mathrm{~m}^{2}$ metal frame was randomly launched at two plot sites. The above-ground plant material was 
cut, washed and then dried in a forced circulation oven at $65{ }^{\circ} \mathrm{C}$ until it reached constant mass. Dry mass results were expressed in $\mathrm{kg} \cdot \mathrm{ha}^{-1}$.

In the plant material, the chemical analysis of the tissue was performed for the elements: nitrogen $(\mathrm{N})$; phosphorus $(\mathrm{P})$; potassium $(\mathrm{K})$; calcium $(\mathrm{Ca})$; magnesium $(\mathrm{Mg})$; sulfur $(\mathrm{S})$; boron $(\mathrm{B})$; copper $(\mathrm{Cu})$; iron $(\mathrm{Fe})$; manganese $(\mathrm{Mn})$ and zinc $(\mathrm{Zn})$. The methods used to analyze the nutrients after wet digestion (nitroperchloric) were: $\mathrm{N}$-Kjeldahl method; $\mathrm{P}$ - colorimetry; $\mathrm{K}$ - flame photometry; $\mathrm{Ca}, \mathrm{Mg}, \mathrm{Cu}, \mathrm{Fe}, \mathrm{Mn}$ and $\mathrm{Zn}$ - atomic absorption spectrometry; B - Azomethine $\mathrm{H}$ procedure; $\mathrm{S}-\mathrm{BaCl}_{2}$ method (Miyazawa et al. 2009). The nutrient accumulation was estimated from the nutrient content present in each plant tissue and the total dry biomass.

\section{Soybean cultivation, management and productivity}

Soybean in the 2017/2018 cropping season was sown on December 13, 2017 after mulching by cover crops. The soybean cultivar used was M8808 IPRO, with a row spacing of $0.5 \mathrm{~m}$, with a population of 200,000 plants $\cdot \mathrm{ha}^{-1}$. Each plot consisted of $5 \mathrm{~m}$ in length and 11 soybean lines (for useful area, the end lines and $0.5 \mathrm{~m}$ of each row were disregarded). The fertilization used in planting was $300 \mathrm{~kg} \cdot \mathrm{ha}^{-1}$ of formula 10-30-10 (NPK) and $150 \mathrm{~kg} \cdot \mathrm{ha}^{-1}$ of $\mathrm{KCl}$ were top dressing applied. At sowing, soybean seeds were inoculated with Bradyrhizobium japonicum.

During the soybean cycle, the phytosanitary management consisted of two applications of the fungicides propiconazole + diphenoconazole (Score Flexi-150 mL·ha ${ }^{-1}$ ) were applied, one at 30 days after emergence (DAE) and one within 20 days after the first application. In addition, the fungicides azoxystrobin + ciproconazole (Priori Xtra- $300 \mathrm{~mL} \cdot \mathrm{ha}^{-1}$ ) and mancozeb (Unizeb Gold) were applied at $70 \mathrm{DAE}$, with a second application of both 20 days later. The control of pests was performed with four applications of tiametoxam + lambda-cyhalothrin (Engeo Full S-300 $\mathrm{mL} \cdot \mathrm{ha}^{-1}$ ), being the first at $30 \mathrm{DAE}$, and three applications with an interval of 20 days each. Piriproxifem (Epingle- $250 \mathrm{~mL} \cdot \mathrm{ha}^{-1}$ ) was applied at $90 \mathrm{DAE}$.

Grain yield was evaluated when soybean reached the harvest point at 115 days after emergence by collecting three rows of $2 \mathrm{~m}$ in length in each experimental unit, correcting grain moisture to $13 \%$ and estimated in $\mathrm{kg}^{\cdot \mathrm{ha}^{-1}}$.

\section{Sampling and microbial soil analysis}

After soybean harvesting, soil samples were collected, one in each subplot, at a depth of 0-0.1 m, and sent to microbial analysis.

The soil microbial biomass carbon and nitrogen ( $\mathrm{MBC}$ and $\mathrm{MBN}$, respectively) were analyzed by the irradiationextraction method and the soil basal respiration was determined by quantifying $\mathrm{CO}_{2}$ released after 7 days of incubation under aerobic conditions. The metabolic quotient $\left(\mathrm{qCO}_{2}\right)$ was obtained by the relationship between soil basal respiration and MBC, according to the methodology described by Mendonça and Matos (2005).

Enzyme activities were analyzed by the methodologies described by Frighetto and Valarini (2000), where enzymatic activities in the respiratory chain were obtained by fluorescein diacetate hydrolysis (FDA) and dehydrogenase activity (DH) analyzed after chloride addition triphenyltetrazolium (TTC) by spectrophotometry.

\section{Statistical analysis}

Results were submitted to analysis of variance and, when significant, the Scott-Knott grouping test was performed $(\mathrm{p}<0.05)$ using the statistical program SISVAR (Ferreira 2014). In order to observe the influence of soil tillage and cover crops use on microbial properties, nutrient cycling and soybean yield, multivariate analysis was performed using the principal component analysis (PCA) technique, presented by biplot graphics. Biplot graphs were prepared considering the first two main components with the largest variances and eigen values greater than 1.0 (Mora-Aguilera et al. 1993). In addition, the importance of variation factors was assessed by the amount of variation explained by each of them in relation to the total variation. 


\section{RESULTS AND DISCUSSION}

\section{Dry mass and nutrient accumulation by cover crops}

There were no interaction effects considering the factors (soil tillage and cover crops) for dry mass production (DM) and nutrient accumulation (Table 2). There was significant effect of soil tillage for $\mathrm{N}, \mathrm{Ca}, \mathrm{Mg}$ and $\mathrm{Cu}$, with higher values for minimum tillage (MT) with $116,54.23$ and $47 \mathrm{~kg} \cdot \mathrm{ha}^{-1}$ of these nutrients compared to no-tillage (NT) with $99,45,19$ and $41 \mathrm{~kg} \cdot \mathrm{ha}^{-1}$, respectively (Table 2 ).

The higher accumulation of N, Ca, Mg and $\mathrm{Cu}$ in plants grown in MT in relation to NT is due to the disking tillage in the $0-0.3 \mathrm{~m}$ layer, which promotes root growth of cover crops during the first year of the experiment. Minimum tillage improves soil aeration, consequently water infiltration is increased and nutrient uptake by cultivated plants is favored (Calonego et al. 2017).

Cover plants differed in DM production and nutrient accumulation, except Ca and Mn (Table 2). Among the plants, millet and intercropping millet + C. spectabilis presented higher DM production, 8,034 and $8,186 \mathrm{~kg} \cdot \mathrm{ha}^{-1}$, respectively. In the same region of this study, Sousa et al. (2019) obtained similar values of DM and Pacheco et al. (2017) found higher values of approximately $11,000 \mathrm{~kg} \cdot \mathrm{ha}^{-1}$. Among other factors, the higher DM production of millet is associated with its better adaptation to local edaphoclimatic conditions and its rapid growth, expressing high potential for use in the region, with efficient cover by its residues and remaining longer on the soil surface in relation to the other cover crops (Borges et al. 2015; Sousa et al. 2019).

The intercropping of millet + C. spectabilis presented an increment of DM and accumulation of $\mathrm{N}$, contrary to the results obtained by Sousa et al. (2019), who found lower values in this intercropping in the same region of this study. This occurs because other factors may influence the DM production of cover crops, such as: crop management, soil fertility, seed quality and germination, plant stand, and the cutting season. Despite the lower DM production in intercropping of millet + C. spectabilis, obtained by Sousa et al. (2019), the mulch produced presented lower decomposition rate, so the soil surface remained longer covered, suggesting this intercropping as an option to implement no-tillage in the region.

The largest accumulations of $\mathrm{N}$ and $\mathrm{Mg}$ occurred with the intercropping millet + C. spectabilis $\left(136\right.$ and $\left.28 \mathrm{~kg} \cdot \mathrm{ha} \mathrm{a}^{-1}\right)$, millet (128 and $24 \mathrm{~kg} \cdot \mathrm{ha}^{-1}$ ) and C. ochroleuca (125 and $25 \mathrm{~kg} \cdot \mathrm{ha}^{-1}$ ), respectively. Millet accumulated $\mathrm{N}$ and Mg in lower

Table 2. Dry mass production and nutrient accumulation in the above ground mass of the cover plants cultivated in no-tillage and minimum tillage.

\begin{tabular}{|c|c|c|c|c|c|c|c|c|c|c|c|c|}
\hline \multirow{2}{*}{ Soil tillage (ST) } & DM & $\mathbf{N}$ & $\mathbf{P}$ & $\mathbf{K}$ & $\mathrm{Ca}$ & $\mathrm{Mg}$ & S & B & $\mathrm{Cu}$ & $\mathrm{Fe}$ & Mn & Zn \\
\hline & $\mathrm{kg} \cdot \mathrm{ha}^{-1}$ & \multicolumn{6}{|c|}{$\mathrm{kg} \cdot \mathrm{ha}^{-1}$} & \multicolumn{5}{|c|}{$\mathbf{g} \cdot \mathbf{h a}^{-1}$} \\
\hline Minimum tillage (MT) & 6857 & $116 a$ & 20 & 136 & $54 a$ & $23 a$ & 16 & 503 & $47 a$ & 7329 & 659 & 283 \\
\hline No-tillage (NT) & 6320 & $99 b$ & 18 & 124 & $45 b$ & $19 b$ & 14 & 496 & $41 b$ & 8121 & 579 & 248 \\
\hline Test F & ns & * & ns & ns & * & * & ns & ns & * & ns & ns & ns \\
\hline \multirow{2}{*}{ Cover crops (CC) } & DM & $\mathbf{N}$ & $\mathbf{P}$ & $\mathbf{K}$ & $\mathrm{Ca}$ & $\mathrm{Mg}$ & $\mathbf{S}$ & B & $\mathrm{Cu}$ & $\mathrm{Fe}$ & Mn & $\mathrm{Zn}$ \\
\hline & $\mathbf{k g} \cdot \mathrm{ha}^{-1}$ & \multicolumn{6}{|c|}{$\mathbf{k g} \cdot \mathrm{ha}^{-1}$} & \multicolumn{5}{|c|}{$g \cdot h a^{-1}$} \\
\hline C. ochroleuca & $5447 c$ & $125 a$ & $15 b$ & $108 b$ & 41 & $25 a$ & $16 a$ & $400 \mathrm{~b}$ & $47 a$ & $3179 b$ & 443 & $282 a$ \\
\hline C. spectabilis & $4393 c$ & $82 b$ & $13 b$ & $82 b$ & 51 & $12 b$ & $8 b$ & $477 \mathrm{~b}$ & $28 b$ & $7088 b$ & 368 & $168 \mathrm{~b}$ \\
\hline Millet + C. spectabilis & $8186 a$ & $136 a$ & $23 a$ & $158 a$ & 60 & $28 a$ & $13 a$ & $420 b$ & $59 a$ & $6993 b$ & 737 & $321 a$ \\
\hline Millet & $8034 a$ & $128 a$ & $26 a$ & $171 a$ & 55 & $24 a$ & $17 a$ & $360 b$ & $51 a$ & $5931 b$ & 1111 & 289 \\
\hline Brachiaria & $6882 b$ & $67 b$ & $19 \mathrm{~b}$ & $131 a$ & 40 & $18 b$ & $19 a$ & $840 a$ & $35 b$ & $15484 a$ & 437 & 267 \\
\hline Test F & * & * & * & * & ns & * & * & * & * & * & ns & * \\
\hline $\mathrm{ST} \times \mathrm{CC}$ & ns & ns & ns & ns & ns & ns & ns & ns & ns & ns & ns & ns \\
\hline $\mathrm{CV}_{1}(\%)$ & 12 & 17 & 13 & 12 & 16 & 15 & 17 & 17 & 15 & 40 & 17 & 16 \\
\hline $\mathrm{CV}_{2}(\%)$ & 13 & 23 & 21 & 21 & 38 & 27 & 23 & 44 & 21 & 26 & 65 & 27 \\
\hline
\end{tabular}

DM: dry mass; N: nitrogen; P: phosphorus; K: potassium; Ca: calcium; Mg: magnesium; S: sulfur; B: boron; Cu: copper; Fe: iron; Mn: manganese and Zn: zinc. ${ }^{1}$ Coefficient of variation. ${ }^{2}$ Subplot coefficient of variation. Means followed by the same letter, in the column, do not differ from each other by the Scott-Knott test ( $p<0.05$ ) 
amounts than found by Costa et al. (2015). These authors observed that in two consecutive crop years using millet as cover crop under oxisol, the accumulation of nutrients was 139 and $200 \mathrm{~kg} \cdot \mathrm{ha}^{-1}$ of $\mathrm{N}$ and 40 and $32 \mathrm{~kg} \cdot \mathrm{ha}^{-1}$ of Mg in both crop years, respectively.

The largest accumulations of $\mathrm{P}$ and $\mathrm{K}$ occurred with millet (26 and $171 \mathrm{~kg} \cdot \mathrm{ha}^{-1}$, respectively), and intercropping millet + C. spectabilis ( 23 and $158 \mathrm{~kg} \cdot \mathrm{ha}^{-1}$, respectively). Other studies already reported the ability of millet to accumulate $\mathrm{K}$ (Pacheco et al. 2013; 2017) and this may be related, among other factors, to its high dry mass production in response to the good soil fertility conditions.

Among the micronutrients, only Mn showed similar accumulation among the evaluated plants. The highest accumulation of B and Fe occurred after brachiaria cultivation with 840 and 15,484 $\mathrm{g} \cdot \mathrm{ha}^{-1}$, respectively. However, this cover plant presented lower accumulated values for $\mathrm{Cu}\left(35 \mathrm{~g} \cdot \mathrm{ha}^{-1}\right)$ and was similar to C. spectabilis, which in turn also presented smaller accumulation of $\mathrm{Zn}\left(168 \mathrm{~g} \cdot \mathrm{ha}^{-1}\right)$. The results obtained for Fe corroborate those obtained by Pittelkow et al. (2012), who studied the accumulation of nutrients in different cover crops in a Brazilian Cerrado oxisol, observed higher Fe accumulation in the brachiaria $\left(2,823 \mathrm{~g} \cdot \mathrm{ha}^{-1}\right)$, although these values are lower than those obtained in the present study.

\section{Soil microbial attributes}

Interaction of cover crops and soil tillage was verified for all microbial attributes evaluated after the soybean harvest (Table 3).

Similar MBC was observed for cover crops grown in MT, however there was difference in the NT system (Table 4). The spontaneous plants in NT presented lower MBC value $\left(142.6 \mathrm{~g} \cdot \mathrm{kg}^{-1}\right)$, similar to C. ochroleuca $\left(168.2 \mathrm{~g} \cdot \mathrm{kg}^{-1}\right)$. However, the intercropping millet + C. spectabilis and single millet presented higher MBC values in NT compared to MT system, which may be related to the high dry mass production and available of nutrients in these treatments, associated with no soil disturbance, factors that favor microbial growth (Amorim et al. 2020).

The associated use of cover crops in no-tillage system increased $\mathrm{MBC}$ values, regardless of the cover used and in minimum tillage, only legume cover crops increased MBC values (Quadros et al. 2012). The lower microbial carbon biomass in disking tilled soil is probably due to disturbances caused by soil tillage by incorporating waste into the soil, increasing soil/waste contact and oxygen availability, stimulating faster degradation and decreasing the microbial community (Lange et al. 2014).

For MBN, in both tillage systems, the spontaneous plants differed from other used plants, with the lowest values of 1.8 and $1.7 \mathrm{~g} \cdot \mathrm{kg}^{-1}$ in NT and MT, respectively. There was no difference between NT and MT and between the studied plants. Similarly, Santos et al. (2015) evaluated cropping systems using soybean/Urochloa brizantha; soybean/spontaneous plants; soybean/corn; soybean/corn + Urochloa ruziziensis and also did not observe difference of MBN between the evaluated production systems.

The results present in this study also corroborate those obtained by Ferreira et al. (2017), who observed similar soil microbial properties of rice crop in succession to cover crops, under no-tillage and minimum tillage systems. Although MBN is as an indicator of soil quality, the use of this variable is not the most appropriate for determining the metabolic status of soil microbial communities, and it can be necessary to consider other microbial indicators of soil quality.

Table 3. Analysis of variance for soil microbial biomass and enzymatic activity affected by tillage and cover crops.

\begin{tabular}{|c|c|c|c|c|c|c|}
\hline Factors of Variation & MBC & MBN & Respiration & FDA & DH & $\mathrm{qCO}_{2}$ \\
\hline Soil tillage (ST) & ns & ns & ns & * & * & ns \\
\hline Cover crops (CC) & * & * & * & * & * & * \\
\hline $\mathrm{ST} \times \mathrm{CC}$ & * & * & * & * & * & * \\
\hline CV1(\%) & 9.7 & 12.9 & 11.4 & 11.8 & 15.4 & 20.3 \\
\hline CV2(\%) & 8.4 & 7.6 & 16.7 & 9.9 & 8.9 & 22.6 \\
\hline
\end{tabular}

MBC and MBN: Microbial biomass carbon and nitrogen, respectively; FDA: fluorescein diacetate hydrolysis; $\mathrm{DH}$ : dehydrogenase; $\mathrm{qCO}_{2}$ : metabolic quotient. *Significant $(p<0.05)$; ns: no significant by Scott-Knott test. 
Table 4. Interaction of cover crops and soil tillage on microbial biomass and enzymatic activity, in the soil depth of 0-0.1 m.

\begin{tabular}{|c|c|c|c|c|c|c|}
\hline \multirow{3}{*}{ Cover crops (CC) } & \multicolumn{2}{|c|}{ MBC } & \multicolumn{2}{|c|}{ MBN } & \multicolumn{2}{|c|}{ SBR } \\
\hline & \multicolumn{4}{|c|}{$\mathbf{g} \cdot \mathbf{k g}^{-1}$} & \multicolumn{2}{|c|}{$\mu \mathrm{gCO}_{2} \cdot \mathrm{g}^{-1} \cdot \mathrm{day}^{-1}$} \\
\hline & NT & MT & NT & MT & NT & MT \\
\hline Spontaneous vegetation & $142.6 b^{1}$ & 156.9aA & $1.8 \mathrm{bA}$ & $1.7 \mathrm{bA}$ & $18.8 \mathrm{aA}$ & $16.9 \mathrm{bA}$ \\
\hline C. ochroleuca & $168.2 \mathrm{bA}$ & $177.4 a \mathrm{~A}$ & $2.5 \mathrm{aA}$ & $2.5 \mathrm{aA}$ & $9.1 \mathrm{bB}$ & $15.4 \mathrm{bA}$ \\
\hline C. spectabilis & 196.9aA & $216.5 a A$ & 2.7aA & 2.7aA & $11.0 \mathrm{bA}$ & $9.4 \mathrm{cA}$ \\
\hline Brachiaria & $218.18 a A$ & 195.1aA & $2.8 \mathrm{aA}$ & $2.3 a \mathrm{~A}$ & $18.7 \mathrm{aA}$ & $19.7 \mathrm{aA}$ \\
\hline Millet & $232.6 \mathrm{aA}$ & 189.9aB & $2.8 \mathrm{aA}$ & $2.4 \mathrm{aA}$ & $15.4 a A$ & $15.0 \mathrm{bA}$ \\
\hline \multirow[t]{4}{*}{ Millet $+C$. spectabilis } & $233.5 \mathrm{aA}$ & $182.8 \mathrm{aB}$ & $2.4 \mathrm{aA}$ & $2.4 \mathrm{aA}$ & $17.9 \mathrm{aA}$ & $7.6 \mathrm{cB}$ \\
\hline & \multicolumn{2}{|c|}{$\mathrm{qCO}_{2}$} & \multicolumn{2}{|c|}{ FDA } & \multicolumn{2}{|c|}{ DH } \\
\hline & \multicolumn{2}{|c|}{$\mathrm{mg} \mathrm{CO}_{2} \cdot \mathrm{mg}^{-1}$} & \multicolumn{2}{|c|}{$\mu \mathbf{g} \cdot \mathbf{g}^{-1}$} & \multicolumn{2}{|c|}{$\mu \mathrm{l} \cdot \mathrm{g}^{-1}$} \\
\hline & NT & MT & NT & MT & NT & MT \\
\hline Spontaneous vegetation & $0.13 a A$ & $0.10 \mathrm{aA}$ & $14.6 \mathrm{cA}$ & $16.5 \mathrm{bA}$ & $2.2 \mathrm{bA}$ & $1.2 \mathrm{bB}$ \\
\hline C. ochroleuca & $0.05 \mathrm{bB}$ & $0.08 \mathrm{aA}$ & $22.6 \mathrm{bA}$ & $23.3 \mathrm{aA}$ & $3.4 a \mathrm{~A}$ & $2.6 \mathrm{aB}$ \\
\hline C. spectabilis & $0.05 \mathrm{bA}$ & $0.04 \mathrm{bA}$ & $13.0 \mathrm{cA}$ & $16.4 \mathrm{bA}$ & $2.5 \mathrm{bA}$ & $1.9 a \mathrm{~A}$ \\
\hline Brachiaria & $0.08 \mathrm{bA}$ & $0.10 \mathrm{aA}$ & $26.5 a A$ & $24.5 \mathrm{aA}$ & $2.6 \mathrm{bA}$ & $2.1 \mathrm{aA}$ \\
\hline Millet & $0.06 \mathrm{bA}$ & $0.07 \mathrm{bA}$ & $30.3 a A$ & $16.8 \mathrm{bB}$ & $1.9 \mathrm{bB}$ & $2.6 \mathrm{aA}$ \\
\hline Millet + C. spectabilis & $0.07 \mathrm{bA}$ & $0.04 \mathrm{bB}$ & $28.2 \mathrm{aA}$ & $17.5 \mathrm{bB}$ & $3.6 a A$ & $2.5 \mathrm{aB}$ \\
\hline
\end{tabular}

MBC and MBN: Microbial biomass carbon and nitrogen, respectively; SBR: soil basal respiration; qCO, metabolic quotient; FDA: fluorescein diacetate hydrolysis; DH: dehydrogenase; NT: no-tillage; MT: minimum tillage; Means followed by the same lowercase letter in the column and uppercase in the row do not differ from each other by the Scott-Knott test $(p<0.05)$

Respiration values were changed by cover crops in both soil tillage systems (Table 4). In the NT system, C. ochroleuca and C. spectabilis presented the lowest respiration, differing from the other cover crops. In MT brachiaria cover had higher soil basal respiration $\left(19.7 \mu \mathrm{g} \mathrm{CO}_{2} \cdot \mathrm{g}^{-1} \cdot \mathrm{day}^{-1}\right)$ and differed from other cover crops. The use of $C$. spectabilis and intercropping millet + C. spectabilis under MT presented the lowest soil basal respiration values (9.4 and $7.6 \mu \mathrm{g} \mathrm{CO}_{2} \cdot \mathrm{g}^{-1}$ day, respectively). Comparing soil tillage, the lowest soil basal respiration values occurred in C. ochroleuca in NT $\left(9.1 \mu \mathrm{g} \mathrm{CO}_{2} \cdot \mathrm{g}^{-1} \cdot \mathrm{day}^{-1}\right)$ and in intercropping the millet + C. spectabilis in MT $\left(7.6 \mu \mathrm{g} \mathrm{CO} \cdot \mathrm{g}^{-1} \cdot \mathrm{day}^{-1}\right)$.

Alves et al. (2011) highlight that the efficiency of microbial biomass is related to the lower carbon lost as $\mathrm{CO}_{2}$ by soil basal respiration. Therefore, it is possible to state that $C$. ochroleuca and C. spectabilis were efficient in the microbial biomass accumulation, since a significant fraction of carbon is incorporated into the microbial biomass (Table 4).

The highest values of metabolic quotient $\left(\mathrm{qCO}_{2}\right)$ were observed in spontaneous plants, in relation to the other cover crops, both in NT and MT system ( 0.13 and $0.10 \mathrm{mg} \mathrm{CO} \cdot \mathrm{mg}^{-1} \mathrm{CBM} \cdot \mathrm{day}^{-1}$, respectively). In MT the spontaneous plant cover was similar to C. ochroleuca and brachiaria.

Differences between tillage systems were observed with C. ochroleuca cover which presented lower $\mathrm{qCO}_{2}$ when managed in NT. Intercropping millet + C. spectabilis in MT presented the lowest values.

High $\mathrm{qCO}_{2}$ values, as observed in this study for spontaneous plants, indicate higher energy use to maintain the microbial community, as a result of stress in the system, or the presence of microbial communities in early stages of development (Guimarães et al. 2017). Lower values of $\mathrm{qCO}_{2}$ indicate higher efficiency of microbial biomass, i.e. less carbon (C) is lost as $\mathrm{CO}_{2}$ and higher proportion of $\mathrm{C}$ is incorporated into microbial cells (Primieri et al. 2017).

The FDA is hydrolyzed by various enzymes (lipases, proteases and esterases) present in microorganisms, this way higher FDA values in NT indicate greater microbial activity in this system with the use of millet and intercropping the millet + C. spectabilis (30.3 $\mu \mathrm{g} \cdot \mathrm{g}^{-1}$ and $28.2 \mu \mathrm{g} \cdot \mathrm{g}^{-1}$, respectively) compared to MT system ( $16.8 \mu \mathrm{g} \cdot \mathrm{g}^{-1}$ and $\left.17.5 \mu \mathrm{g} \cdot \mathrm{g}^{-1}\right)$ (Table 4). For the heterotrophic potential of soil microbiota, represented by the activity of enzymes in FDA, grasses presented higher values, which shows a relationship with the higher dry mass production by these plants and, therefore, a higher carbon source favored greater enzymatic activity in these cover crops, corroborating the work of Santos et al. (2015), who obtained 
higher FDA value for brachiaria. The same authors also describe that the greater activity of enzymes in FDA is linked not only to the effects of accumulated residues and higher DM, but also to the presence of soil moisture, which stimulates microbial activity. In the present study, greater activity of enzymes in FDA occurred in no-tillage, possibly because this system provides greater soil moisture, which stimulates microbial processes.

The enzyme dehydrogenase (DH) in NT was higher with C. ochroleuca $\left(3.4 \mu \mathrm{Lg}^{-1}\right)$ and with consortium of millet + C. spectabilis $\left(3.6 \mu \mathrm{Lg}^{-1}\right)$, which differed from the other treatments. The lowest $\mathrm{DH}$ activity in NT occurred with millet cultivation $\left(1.9 \mu \mathrm{Lg}^{-1}\right)$. In MT all cover crops presented higher values than spontaneous plants. Except for C. spectabilis and brachiaria, the other cover plants differed between the SD and CM systems for DH.

Changes in soil physical and chemical properties cause variations in enzymatic activity and can be related to management practices or different dry mass production by cover crops. In this way, higher DH activity in the NT system is related to higher MBC values (Table 4) also found in this soil tillage system. The results obtained in the present study for DH activity corroborate those found by Quadros et al. (2012), in which the no-tillage presented higher enzymatic activity compared to conventional tillage.

The dehydrogenase enzyme plays an important role as an indicator of biochemical processes involved in soil organic matter decomposition and nutrient cycling and availability, in addition it can be used as indicator of soil fertility and quality. This enzyme also participates in the respiratory chain of microorganisms and is directly related to aeration conditions that are dependent on temperature and soil moisture, vegetation composition, management practices, soil $\mathrm{pH}$ and organic matter content (Andrighetti et al. 2014).

\section{Soybean yield}

Soybean yield was influenced only by the cover crops (Fig. 2). The highest soybean yield was obtained after C. ochroleuca and the intercropping millet + C. spectabilis cover crops with values of 3,815 and 4,024 kg.ha-1 ${ }^{-1}$, respectively, with no difference

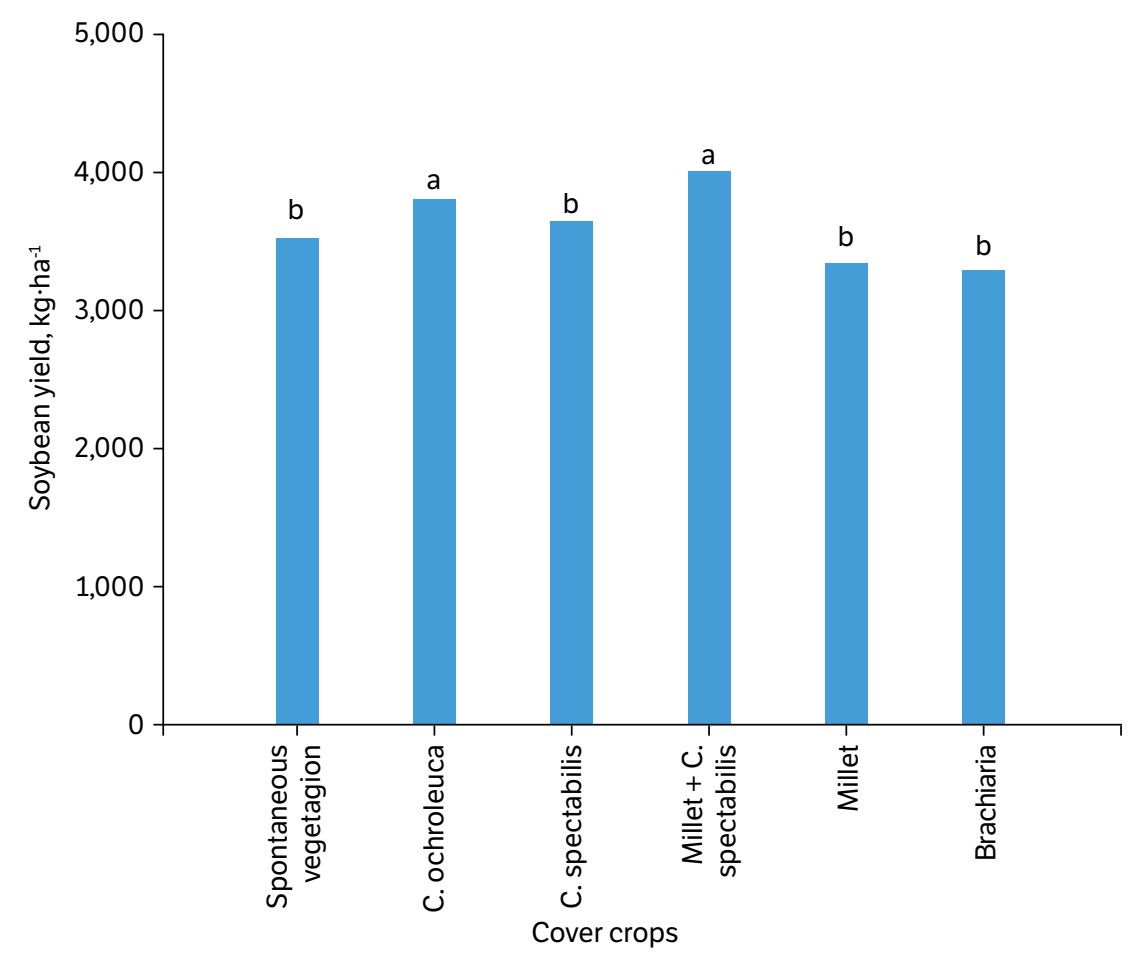

Figure 2. Soybean yield in succession to cover crops, in the Serra do Quilombo (Vô Desidério farm), Bom Jesus, PI. Same letters do not differ by the Scott-Knott test $(p<0.05)$. 
between these treatments. These results indicate that there are improvements in soil conditions in the treatments using legume cover crops. One of the benefits is due to the higher nitrogen accumulation provided by the cultivation of these plants, as shown in Table 2. Although soybean have symbiosis with nitrogen-fixing bacteria, this is the most required and exported nutrient by this crop (Borges et al. 2015). These legume cover species have low C:N ratio and low lignin concentration, which accelerates the decomposition of their residues, makes nutrients readily available in the soil solution and favors their utilization by the sequential crop (Carvalho et al. 2015). The intercropping millet + C. spectabilis, besides higher nutrient cycling, also presented higher microbial biomass when cultivated under no-tillage. Therefore, is possible that these associated factors justify greater soybean productivity in this consortium. The millet, regardless of single or intercropping, provides sufficient $\mathrm{K}$ for the demand for soybeans, which for production of $3,600 \mathrm{~kg}$ of grain, requires an equivalent quantity of $114 \mathrm{~kg} \cdot \mathrm{ha}^{-1}$ of $\mathrm{K}$ (Embrapa, 2013). The amount of $\mathrm{N}$ and $\mathrm{K}$ in the millet residues indicates that, although it is not a legume, it has great nutritional potential to supply the following crops (Pacheco et al. 2017).

However, these nutrients are in organic form and require mineralization to be available the soybean part of $\mathrm{N}$ and $\mathrm{P}$ is rapidly released at the initial stage of decomposition of plant residues (Costa et al. 2015). Thus, it is important to highlight the high amounts of nutrients that can be released and used by crops in succession.

Crotalaria ochroleuca also showed higher productivity, was efficient in cycling nutrients similarly to the consortium and, cultivated under no-tillage, showed low soil basal respiration and $\mathrm{qCO}_{2}$ and high values of $\mathrm{DH}$ enzyme, which indicates the efficiency of the microbial community to assimilate carbon and use nutrients. In a long-term study, Mbuthia et al. (2015) also observed relationship of soil microbial quality and nutrient cycling in the increased cotton yield in no-tillage. The soybean yield was higher than that found by Nascente and Stone (2018), who evaluated the effect of cover crops grown in the off-season and obtained 3,440 kg.ha-1 of soybean when cultivated after intercropping millet + C. ochroleuca under

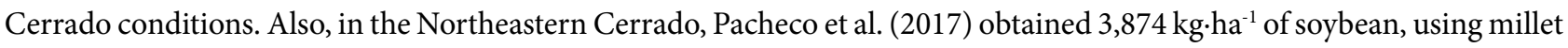
preceding the soybean + brachiaria associated with soybean in the phenological phase R5.6.

\section{Principal component analysis (PCA)}

Principal component analysis (PCA) explained $61 \%$ of the total data variation, with $39 \%$ in the main component 1 (CP1) and $22 \%$ in the component 2 (CP2) (Fig. 3). Through CP1, DM, P, K and Mg were the variables that most influenced the dispersion of the data. And in $\mathrm{CP} 2$, the variables that contributed the most were $\mathrm{Ca}, \mathrm{qCO} 2$ and FDA. It was observed that the use of exclusive millet and intercropping millet + C. spectabilis, regardless of the tillage system, presented higher dry mass production and nutrient accumulation, as observed in Table 2 and discussed above. In addition, the use of the intercropping of these species resulted in higher soybean yield (Fig. 2).

Soil microbial activity, represented by the variables BMC, MBN and DH, showed a positive correlation with soybean yield in this first evaluation after the introduction of cover crops. These observations demonstrate that biomass and soil microbial activity are important, not only as indicators of soil quality, but because they play an important role in nutrient supply to plants (Balota et al. 2014) and these soil components can increase soybean yield. Evaluating long-term experiments, for 12 to 17 years, based on soybean and corn crop yield history, Lopes et al. (2013) found that highly productive soils also have high microbial biomass, soil basal respiration, and soil cellulase enzyme activity. Similarly, Mbuthia et al. (2015), in a long-term study, also observed in addition to improved soil microbiological quality and nutrient cycling, increased yield in no-tillage and mulching compared to conventional tillage and bare soil.

The single millet and the consortium millet + C. spectabilis, in NT system favored MBC, which can be related to the high DM production by these plants (Table 2). Soil microbial biomass still depends on the characteristics of the crop residues, so residues with high $\mathrm{C}: \mathrm{N}$ ratio, such as millet, need more time for decomposition of their biomass reflecting the presence of more active organic matter in the soil (Martínez-García et al. 2018). Microbial biomass carbon is still closely related to respiration since low values of soil basal respiration combined with high $\mathrm{MBC}$ in millet cover show that the biomass of these residues was efficient in carbon accumulation, i.e., less carbon in the form of $\mathrm{CO}_{2}$ lost by respiration, and more incorporation of carbon into microbial tissues (Navroski et al. 2017). 


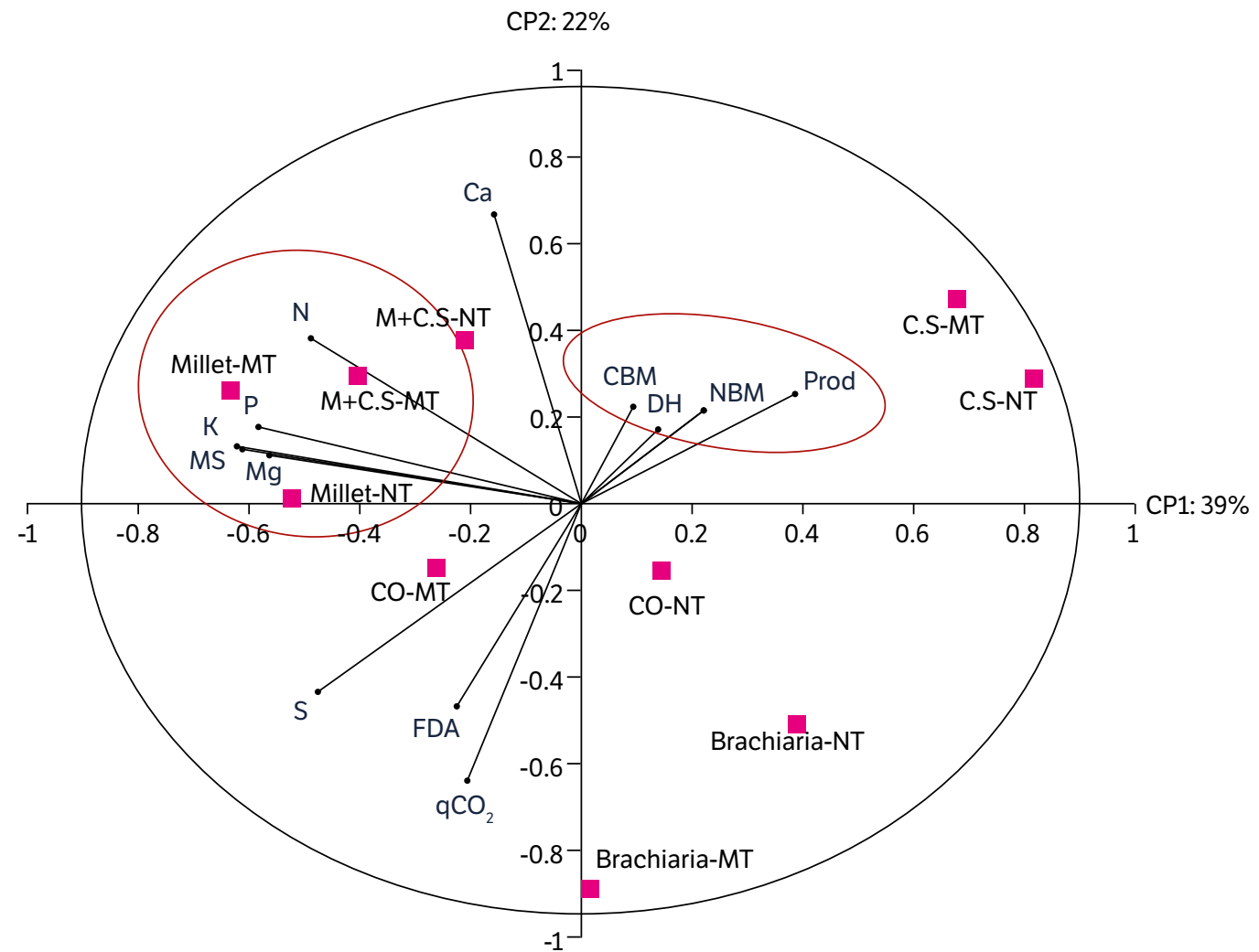

Figure 3. Principal component analysis (PCA), for soil microbial biomass and enzymatic activity, dry mass production, macronutrient cycling and soybean yield, after cover crops in soil tillage systems.

C.S-MT: C. spectabilis in minimum tillage; C.S-NT: C. spectabilis in no-tillage; C.O-MT: C. ochroleuca in minimum tillage; C.O-NT: C. ochroleuca in no-tillage Brachiaria-MT: brachiaria in minimum tillage; Brachiaria-NT: brachiaria in no-tillage; Millet-MT: millet in minimum tillage; Millet-NT: millet in no-tillage; M+C.S-MT: millet + C. spectabilis in minimum tillage; M+C.S-NT: millet + C. spectabilis in no-tillage; DM: dry mass of the cover crops; $\mathrm{N}$ : nitrogen; P: phosphorus; K: potassium; Ca: calcium; Mg: magnesium; S: sulfur; qCO : metabolic quotient; $M B N$ : microbial biomass nitrogen; $M B C$ : microbial biomass carbon; FDA: fluorescein diacetate hydrolysis; DH: dehydrogenase; Prod: Soybean yield.

\section{CONCLUSION}

The highest dry mass production and nutrient cycling in this conservation system occurs with intercropping millet + C. spectabilis and single millet.

The soil microbial activity is promoted by millet, C. ochroleuca and intercropping of millet + C. spectabilis in no-tillage system. Cover crops in conservation systems improve soil microbial quality and increase grain yield even in the first soybean crop season.

\section{FUNDERS}

Embrapa

Grant \# 22.13.11.004.00.03.004

$\mathrm{CNPq}$

Grant \#442506/2014-7

PQ fellowship

Grant \#307908/2017-8 


\section{AUTHOR'S CONTRIBUTION}

Conceptualization: Pires M. F. M.: Medeiros J. C. and Souza H. A.; Methodology: Pires M. F. M.: Nolêto K. C. and Rocha A. G.; Investigation: Pires M. F. M.: Medeiros J. C.: Souza H. A. and Dalla Rosa J.; Writing - Original Draft: Pires M. F. M.: Medeiros J. C.: Souza H. A.; Dalla Rosa J.; Boechat C. L. and Mafra A. L.; Writing - Review and Editing: Pires M. F. M.: Medeiros J. C.: Souza H. A.: Dalla Rosa J.: Boechat C. L. and Mafra A. L.

\section{REFERENCES}

Adler, R. L., Singh, G., Nelson, K. A., Weirich, J., Motavalli, P. P. and Miles, R. J. (2020). Cover crop impact on crop production and nutrient loss in a no-till terrace topography. Journal of Soil and Water Conservation, 75, 153-165. https://doi.org/10.2489/jswc.75.2.153

Almeida, W. S., Panachuki, E., Oliveira, P. T. S., Menezes, S. R., Alves Sobrinho, T. and Carvalho, D. F. (2018). Effect of soil tillage and vegetal cover on soil water infiltration. Soil and Tillage Research, 175, 130-138. https://doi.org/10.1016/j.still.2017.07.009

Alves, T. S., Campos, L. L., Elias Neto, N., Matsuoka, M. and Loureiro, M. F. (2011). Biomassa e atividade microbiana de solo sob vegetação nativa e diferentes sistemas de manejos. Acta Scientiarum. Agronomy, 33, 341-347. https://doi.org/10.4025/actasciagron.v33i2.4841

Amorim, S. P. N., Boechat, C. L., Duarte, L. S. L., Oliveira, D. F., Medeiros, J. C. and Arauco, A. M. S. (2020). Microbial responses to doses of cover plant straw in cerrado piauiense oxisol. Bioscience Journal, 36, 1146-1155. https://doi.org/10.14393/BJ-v36n4a2020-47963

Andrade Junior, A. S., Bastos, E. A., Silva, C. O., Gomes, A. A. N. and Figueredo Júnior, L. G. M. (2004). Atlas climatológico do estado do Piauí [Documentos 101]. Teresina: Embrapa Meio-Norte. [Accessed Feb. 10 2020]. Available at: https://ainfo.cnptia.embrapa.br/digital/ bitstream/item/32199/1/atlas.pdf

Andrighetti, M. S., Nachtigall, G. R., Queiroz, S. C. N., Ferracini, V. L. and Ayub, M. A. Z. (2014). Biodegradação de glifosato pela microbiota de solos cultivados com macieira. Revista Brasileira de Ciência do Solo, 38, 1643-1653. https://doi.org/10.1590/S0100-06832014000500029

Balota, E. L., Calegari, A., Nakatani, A. S. and Coyne, M. S. (2014). Benefits of winter cover crops and no-tillage for microbial parameters in a Brazilian oxisol: A long-term study. Agriculture Ecosystems \& Environment, 197, 31-40. https://doi.org/10.1016/j.agee.2014.07.010

Borges, W. L. B., Freitas, R. S., Mateus, G. P., Sá, M. E. and Alves, M. C. (2015). Produção de soja e milho cultivados sobre diferentes coberturas. Revista Ciência Agronômica, 46, 89-98. https://doi.org/10.1590/S1806-66902015000100011

Calonego, J. C., Raphael, J. P. A., Rigon, J. P. G., Oliveira Neto, L. and Rosolem, C. A. (2017). Soil compaction management and soybean yields with cover crops under no-till and occasional chiseling. European Journal of Agronomy, 85, 31-37. https://doi.org/10.1016/j.eja.2017.02.001

Carvalho, A. M., Coser, T. R., Rein, T. A., Dantas, R. A., Silva, R. R. and Souza, K. W. (2015). Manejo de plantas de cobertura na floração e na maturação fisiológica e seu efeito na produtividade do milho. Pesquisa Agropecuária Brasileira, 50, 551-561. https://doi.org/10.1590/ S0100-204X2015000700005

Castellano-Hinojosa, A. and Strauss, S. L. (2020). Impact of cover crops on the soil microbiome of tree crops. Microorganisms, $8,328$. https://doi.org/10.3390/microorganisms8030328

Chamberlain, L. A., Bolton, M. L., Cox, M. S., Suen, G., Conley, S. P. and Ané, J.-M. (2020). Crop rotation, but not cover crops, influenced soil bacterial community composition in a corn-soybean system in southern Wisconsin. Applied Soil Ecology, 154, 103603. https://doi. org/10.1016/j.apsoil.2020.103603

Costa, N. R., Andreotti, M., Ulian, N. A., Costa, B. S., Pariz, C. M. and Teixeira Filho, M. C. M. (2015). Acúmulo de nutrientes e tempo de decomposição da palhada de espécies forrageiras em função de épocas de semeadura. Bioscience Journal, 31, 818-829. https://doi. org/10.14393/BJ-v31n3a2015-22434 
De Vincentis, A. J., Solis, S. S., Bruno, E. M., Leavitt, A., Gomes, A., Rice, S. and Zaccaria, D. (2020). Using cost-benefit analysis to understand adoption of winter cover cropping in California's specialty crop systems. Journal of Environmental Management, 261, 110205. https:// doi.org/10.1016/j.jenvman.2020.110205

Derpsch, R., Franzluebbers, A. J, Duiker, S. W., Reicosky, D. C., Koeller, K., Friedrich, T., Sturny, W. G., Sá, J. C. M. and Weiss, K. (2014). Why do we need to standardize no-tillage research? Soil and Tillage Research, 137, 16-22. https://doi.org/10.1016/j.still.2013.10.002

[EMBRAPA] Empresa Brasileira de Pesquisa Agropecuária (2013). Tecnologias de produção de soja - Região Central do Brasil 2014. Londrina: Embrapa Soja. [Accessed Jun. 2 2020]. Available at: https://ainfo.cnptia.embrapa.br/digital/bitstream/item/95489/1/SP-16online.pdf

Ferreira, D. F. (2014). Sisvar: a guide for its bootstrap procedures in multiple comparisons. Ciência e Agrotecnologia, 38, 109-112. https:// doi.org/10.1590/S1413-70542014000200001

Ferreira, E. P. B., Stone, L. F. and Martin-Didonet, C. C. G. (2017). População e atividade microbiana do solo em sistema agroecológico de produção. Revista Ciência Agronômica, 48, 22-31. https://doi.org/10.5935/1806-6690.20170003

Frighetto, R. T. S. and Valarini, P. J. (2000). Indicadores biológicos e bioquímicos da qualidade do solo: manual técnico [Documento 21]. Jaguariúna: Embrapa Meio Ambiente. [Accessed Jun. 2 2020]. Available at: https://www.infoteca.cnptia.embrapa.br/infoteca/ bitstream/doc/13251/1/2000DC01.pdf

Guimarães, N. F., Gallo, A. S., Fontanetti, A., Meneghin, S. P., Souza, M. D. B., Morinigo, K. P. G. and Silva, R. F. (2017). Biomassa e atividade microbiana do solo em diferentes sistemas de cultivo do cafeeiro. Revista de Ciências Agrárias, 40, 34-44. https://doi.org/10.19084/ RCA16041

Lange, M., Habekost, M., Eisenhauer, N., Roscher, C., Bessler, H., Engels, C., Yvonne Oelmann, Y., Scheu, S., Wilcke, W., Schulze, E.-D. and Gleixner, G. (2014). Biotic and abiotic properties mediating plant diversity effects on soil microbial communities in an experimental grassland. PLoSONE, 9, e96182. https://doi.org/10.1371/journal.pone.0096182

Lopes, A. A. C., Sousa, D. M. G., Chaer, G. M., Reis Junior, F. B., Goedert, W. J. and Mendes, I. C. (2013). Interpretation of microbial soil indicators as a function of crop yield and organic carbon. Soil Science Society of America Journal, 77, 461-472. https://doi.org/10.2136/ sssaj2012.0191

Martínez-García, L. B., Korthals, G., Brussaard, L., Jørgense, H. B. and Deyn, G. B. (2018). Organic management and cover crop species steer soil microbial community structure and functionality along with soil organic matter properties. Agriculture Ecosystems and Environment, 263, 7-17. https://doi.org/10.1016/j.agee.2018.04.018

Mbuthia, L. W., Acosta-Martínez, V., Bruyn, J., Schaeffer, S., Tyler, D., Odoi, E., Mpheshea, M. and Eash, N. (2015). Long term tillage, cover crop and fertilization effects on microbial community structure, activity: Implications for soil quality. Soil Biology and Biochemistry, 89, 24-34. https://doi.org/10.1016/j.soilbio.2015.06.016

Mendonça, E. S. and Matos, E. S. (2005). Matéria orgânica do solo: Métodos de análises. Viçosa: UFV.

Merten, G. H., Araújo, A. G., Biscaia, R. C. M., Barbosa, G. M. C. and Conte, O. (2015). No-till surface runoff and soil losses in southern Brazil. Soil and Tillage Research, 152, 85-93. https://doi.org/10.1016/j.still.2015.03.014

Miyazawa, M., Pavan, M. A., Muraoka, T., Carmo, C. A. F. S. and Melo, W. J. (2009). Análise química de tecido vegetal. In: F. C. Silva (Org.), Manual de análises de solos, plantas e fertilizantes (p. 191-234). Brasília: Embrapa Informação Tecnológica.

Mora-Aguilera, G., Nieto-Angel, D., Téliz, D. and Campbell, C. L. (1993). Development of a Prediction Model for Papaya Ringspot in Veracruz, Mexico.

Nascente, A. S. and Stone, L. F. (2018). Cover crops as affecting soil chemical and physical properties and development of upland rice and soybean cultivated in rotation. Rice Science, 25, 340-349. https://doi.org/10.1016/j.rsci.2018.10.004 
Navroski, D., Moreira, A., Colozzi-Filho, A. and Grange L. (2017). Atributos microbiológicos do solo em diferentes sistemas de manejo no oeste paranaense. Agrotrópica, 29, 127-134.

Osterholz, W. R., Culman, S. W., Herms, C., Oliveira, F. J., Robinson, A. and Doohan, D. (2020). Knowledge gaps in organic research: understanding interactions of cover crops and tillage for weed control and soil health. Organic Agriculture. https://doi.org/10.1007/ s13165-020-00313-3

Pacheco, L. P., Barbosa, J. M., Leandro, W. M., Machado, P. L. O., Assis, R. L., Madari, B. E. and Petter, F. A. (2013). Ciclagem de nutrientes por plantas de cobertura e produtividade de soja e arroz em plantio direto. Pesquisa Agropecuária Brasileira, 48, 1228-1236. https://doi. org/10.1590/S0100-204X2013000900006

Pacheco, L. P., Monteiro, M. M. S., Petter, F. A., Nóbrega, J. C. A. and Santos, A. S. (2017). Biomass and nutrient cycling by cover crops in Brazilian Cerrado in the state of Piauí. Revista Caatinga, 30, 13-23. https://doi.org/10.1590/1983-21252017v30n102rc

Pittelkow, F. K., Scaramuzza, J. F., Weber, O. L. S., Maraschin, L., Valadão, F. C. A. and Oliveira, E. S. (2012). Produção de biomassa e acúmulo de nutrientes em plantas de cobertura sob diferentes sistemas de preparo do solo. Agrarian, 5, $212-222$.

Primieri, S., Muniz, A. W. and Lisboa, H. M. (2017). Dinâmica do carbono no solo em ecossistemas nativos e plantações florestais em Santa Catarina. Floresta e Ambiente, 24, e00110314. https://doi.org/10.1590/2179-8087.110314

Quadros, P. D., Zhalnina, K., Davis-Richardson, A., Fagen, J. R., Drew, J., Bayer, C. and Triplett, E. W. (2012). The effect of tillage system and crop rotation on soil microbial diversity and composition in a subtropical acrisol. Diversity, 4, 375-395. https://doi.org/10.3390/d4040375

Santos, F. L., Paulino, H. B., Carneiro, M. A. C., Caetano, J. O., Benites, M. V. and Souza, E. D. (2015). Atributos bioquímicos do solo sob diferentes sistemas de produção no sudoeste goiano. Global Science and Technology, 8, 74-86. https://doi.org/10.14688/1984-3801/ gst.v8n2p74-86

Soil Survey Staff (2014). Keys to soil taxonomy. Washington: United States Department of Agriculture, Natural Resources Conservation Service.

Sousa, D. C., Medeiros, J. C., Lacerda, J. J. J., Dalla Rosa, J., Boechat, C. L., Souza, M. N. G., Rodrigues, P. C. F., Oliveira Filho, E. G. and Mafra, Á. L. (2019). Dry mass accumulation, nutrients and decomposition of cover plants. Journal of Agricultural Science, 11, 152-160.

In the article Conservation system improves soil microbial quality and increases soybean yield in the Northeastern Cerrado with DOI: https://doi.org/10.1590/1678-4499.20200117, published in Bragantia vol.79 no.4 Campinas Oct./Dec. 2020:

In the footline where is read Bragantia, Campinas, v. 79, n. 4, p.474-486, 2020 should be read Bragantia, Campinas, v. 79, n. 4, p.599-611, 2020. 